\title{
الابتلاءات في طريق الاعوة إلى الله تعالى
}

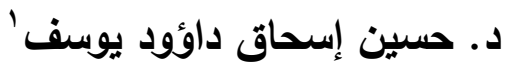

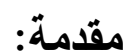

الحمد لله ربِّ العالمين والصـلاة والسـلام على أثشرف الأنبياء والمرسلين

سيدنا محمد وعلى آله وصحبه أجمعين.

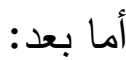

فإن الله خلق الخلق ليعبدوه ويوحدوه، كما دلت على ذلك الأدلة مثل قوله

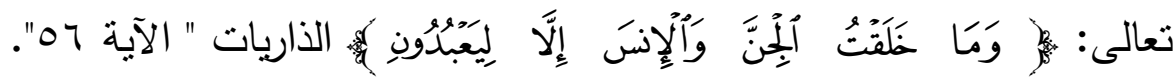

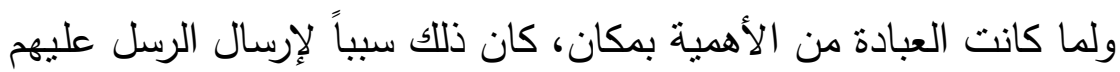

السلام، وأنزل عليهم الكتب ليبينوا حقيقة هذه العبادة للجن والإنس التي من أجلها

خلقهم الله، وتوضيح ذلك وبيانها وتقصيله، وحتى يقوموا بهذه العبادة على الوجها

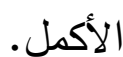

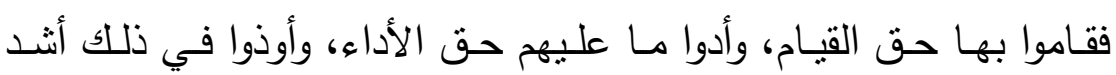

الأذى، وصبروا على ذلك البلاء والأذى وتلك الثدة، أنثد الصبر .

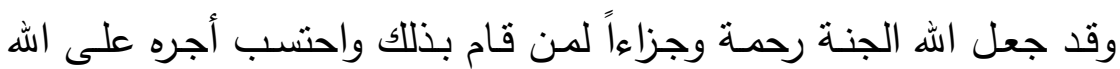

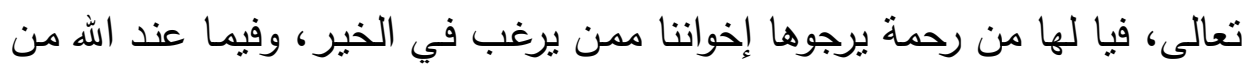
تلك الرحمة وذلك الأجر العظيم.

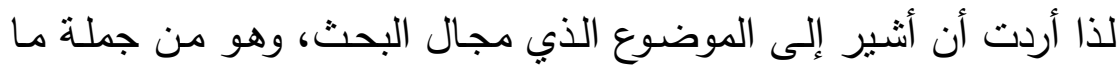

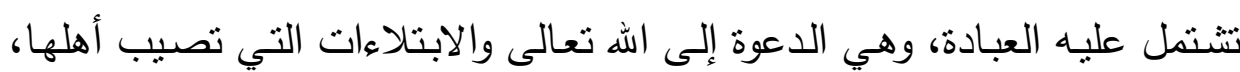

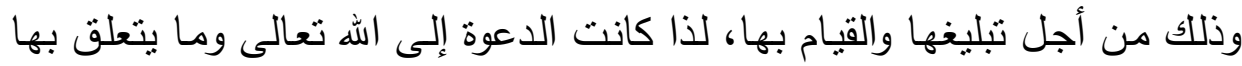

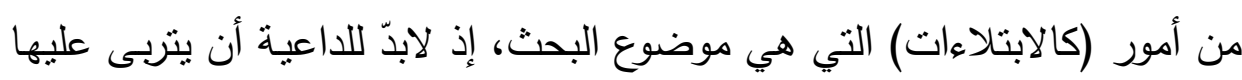

' أستاذ مساعد - كلية الدعوة الإسلامية - جامعة أم درمان الإسلامية.

- roo- 
ويعيها ويفقها جيداً، وهي من أفضل الأعمال وأجلها عند الهه تعالى، قال تعالى:

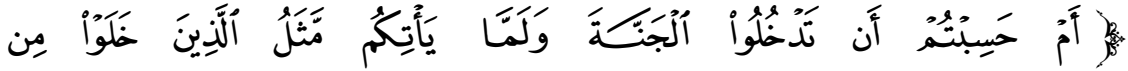

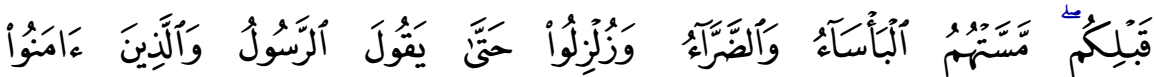

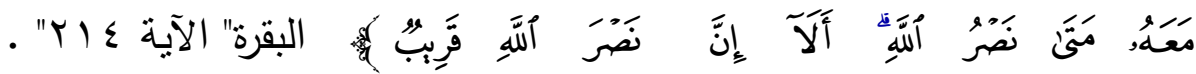

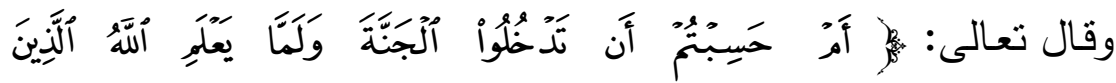

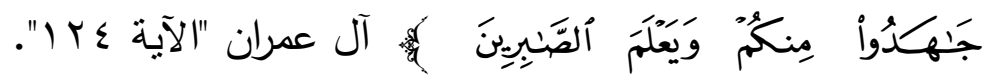
لذا كان من واجب الداعية إلى الله تعالى أن يعرف ما لـه وما عليه تجاه دعوته حتى لا يكثر من التخبط والتردي والنكوص على الأعقاب إذا ما حدث لـه شيء من الإبتلاءات في سبيل دعوته. عافانا الله وإياكم في الدارين.

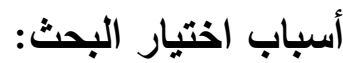

ا ـ لأن الابتنلاء سنة من سنن الله في الكون، وقد ذكر الله عز وجل سـنة

$$
\text { الابتناء في كتابه العزيز عدة مرات. }
$$

r. تذكرة للدعاة في سبيل الله والقـافلين عنـه ممـن لا بعر الاجـر والثواب،

$$
\text { والجزاء المترتب على ذلك الابتلاء. }
$$

r. التأسي برسول الله كثيراً وقد حدث لغيره من الأنبياء والمرسلين عليهم السلام.

ا ـ التعرف على الإبتلاء وأنواعه. r. كثف وبيان الحكمة من الإبتلاء. r. توضيح الاجر والثواب المترتب على الابتلاء. 
تتبع أهمية البحث من كونه يناقش موضوع من أهم المواضيع التي ينبقي

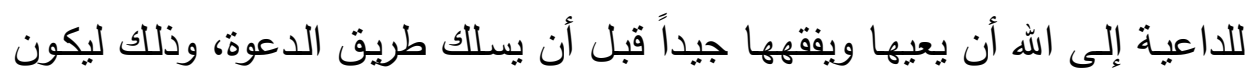
لديه الصبر ولاحتساب فيما يواجهه من ابتلاءات في طريق الدعوة إلى الله تعالى. منهج البحث: لقد اتبع الباحث المنهج الوصفي والتاريخي، ثم التحليلي... للتوصل إلى النتائج والتوصيات التي تقيد في هذا البحث. وقد قسمت هذا البحث إلى عدة مباحث، المبحث الأول تتاولت فيه مفهوم الإبتلاءات، والمبحث الثاني تتاولت فيـه أنواع الإبتلاءات، وفي المبحث الثالث تتاولت فيه الحكمة من الإبتلاءات، وفي المبحث الرابع تناولت فيه الأجر المترتب على الابتلاءات. ثم الخاتمة وتتنتمل على أهم النتائج والتوصيات والفهارس. 


\section{المبحث الأول \\ مفهوم الإبتلاءات}

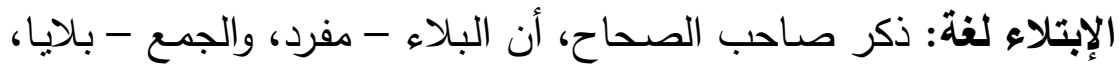

وابتلاءات، وبلاه: جربه واختبره وبابه عَدا ، وبلاه الله اختبره، يبلوه [ بلاءً ] بالدد الإند

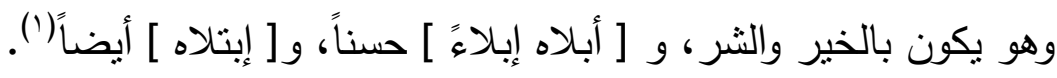

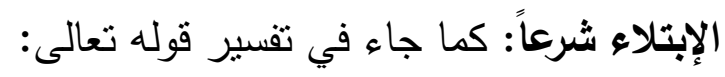

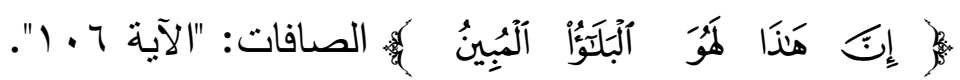

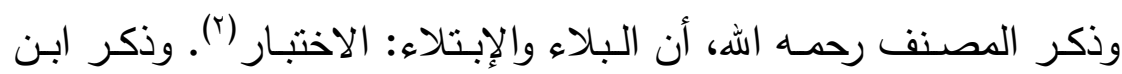

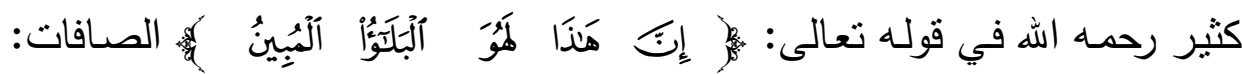

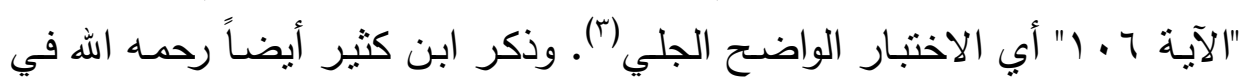

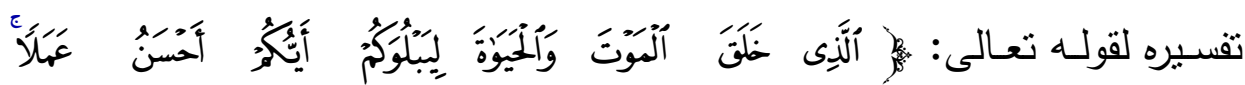

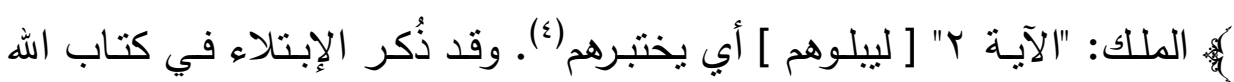

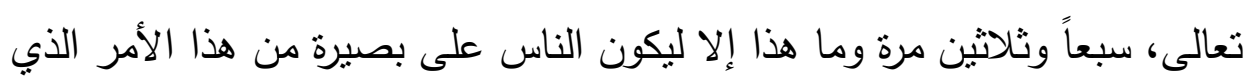

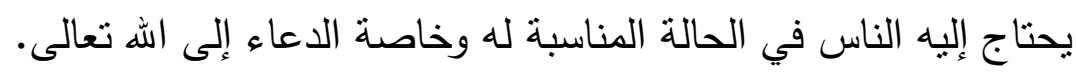
والإبتلاء للأنبياء والرسل والمؤمنين سنة قائمة باقية جارية إلى يوم القيامة.

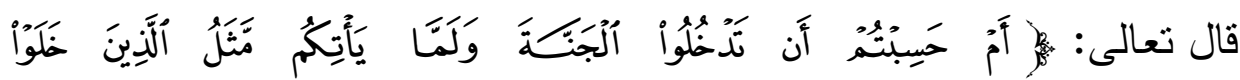

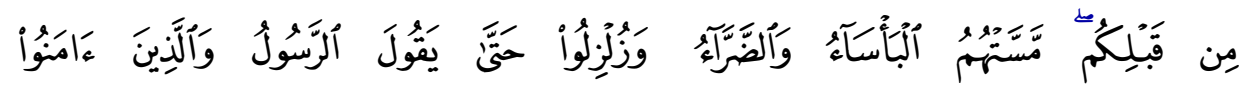

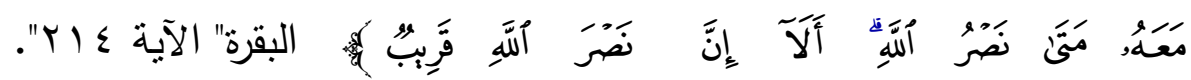

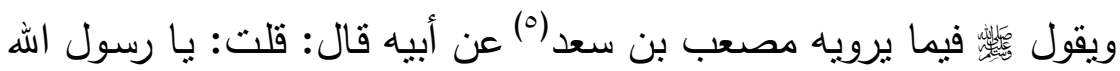

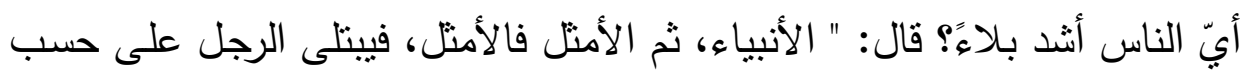

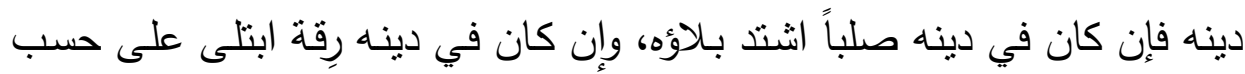

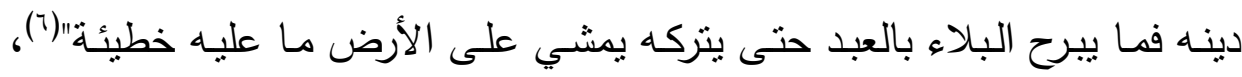


فهكا جرت سنة الله في الأنبياء والصالحين من هذه الأمة، وخاصة الدعاة إلى الله تعالى، وذلك لتمحيصـهم وإعدادهم لينالوا بصبرهم وثباتهم المنزلة العالية عند الله وليرفع درجاتهم بما يصيبهم من الأذى والإبتاء، وبما يحصل لهم من الثـهادة في

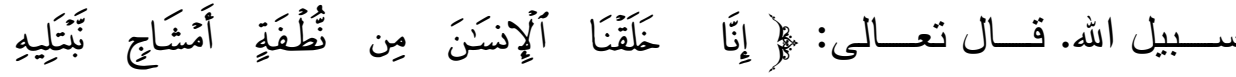

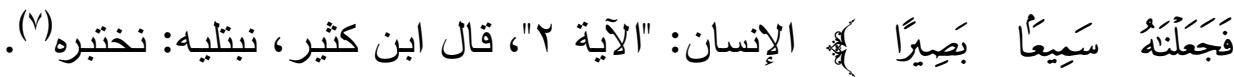
فهذا دليل على أن الله خلق الإنسان لأجل هذا الأمر حتى يتبين الذين صدقوا من الكاذبين.

وقد جاء في قوله تعالى مخاطباً عباده المؤمنين في غزوة أحد بعد الهزيمة، وذلك لمّا خالف بعض الصحابة رضي الله عنهم من الرماة أمر النبي

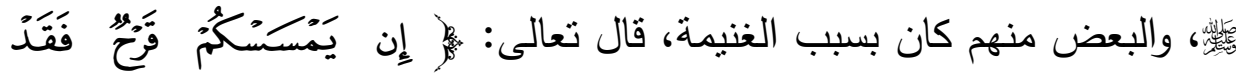

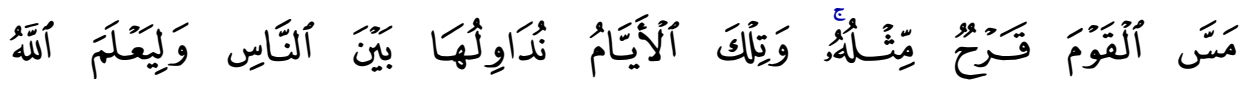

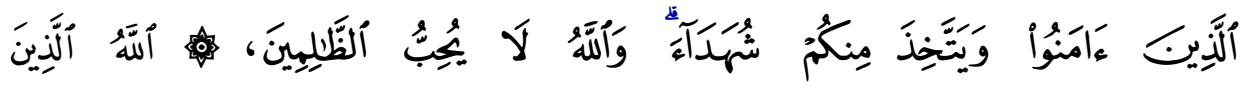

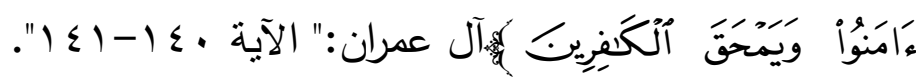
وهذا درب من دروب الإبتلاء وذلك لتمحيص الأنفس واختبارها ووقوفها عند مواطن الخلل وتلافيها له.

وقد ورد ذكر الإبتلاء في كتاب الله تعالى سبعاً وثلاثثن مرة(^). والإبتاء من سنن الله القائمة الباقية الجارية عبر التاريخ والأزمان: فما من نبي إلاّ وقد ابتلى وأوذي وحورب فمنهم من قتل، ومنهم من ألقي في النار، ومنهم من أخرج من أرضـه، وكذلك أتباعهم، فقد نالهم من الابتلاء والأذى والقتل والتتربد والتعذيب صنوف وألوان شتى من أجل دعوتهم، فلما نجحوا في الابتلاء وثثتوا على الحق تتزل عليهم نصر الله تعالى، فأبدلهم من بعد خوفهم أمناً ومكن لهم في الأرض وجعلهم أئهـة وجعلهم الوارثين، كل ذلك سببه، الثبات في الدعوة 
وتحمل البلاء والأذى لنشر هذا الدين والتضحية من أجله، وإعلاء كلمة الله تعالى، والنصر لـذا الدين.

ألا وإن عظم الجزاء مع عظم البلاء، فعن أنس رضـي الله عنه قال: قال: رسول الله فمن رضى فله الرضا، ومن سخط فله السخط"(9). وذكر الثـارح أنـه مـن كـان إبـتلاؤه أعظم فجزاؤه أعظم، ووضــح معنى الإبتلاء، أي الاختبار بالمحن والرزايا [ فمن رضي ] بما ابتلاه به، فله الرضى من الله تعالى وجزيل الثواب [ ومن سخِط ] بكسر الخاء أبيّ كره بـلاء الله تعالى وفزع منه ولم يرض بقضائه، فله السخط من الله تعالى وأليم العذاب، ومن يعمل سوءاً يجز به، والمقصود الحث على الصبر على البلاء بعد وقوعه لا الترغيب في طلبه للنهي عنه(·").

أقول لا شك أن الداعية الذي يسلك هذا الطريق لابدّ له من وقفة مع نفسـه

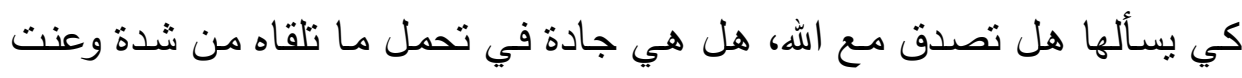
وبلاء وابتلاء، أم تربد الدعة والاستكانة والخلود إلى الأرض وإتباع الهوى والتكاسل هل والقعود مع الخالفين. قـال الفضـيل(')": إن الهه عز وجـل - ليعاهد عبـده المؤمن بـالبـلاء كمـا يتعاهد الرجل أهله بالخير(r').

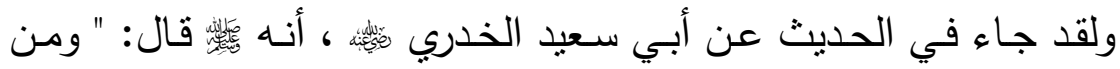
يصبر يُصبِّره الله وما أعطى أحد من عطاء خيراً أوسع من الصبر "(r'). 


\section{المبحث الثاني \\ أنواع الابتلاءات}

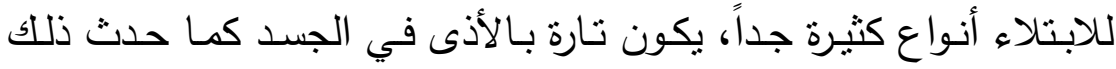

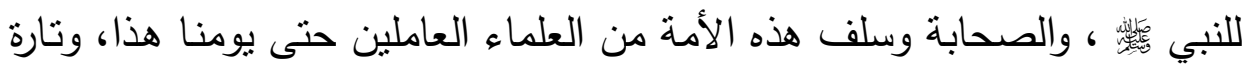
يكون في المال، أو في الأهل، وتارة يكون بالقول، والصحيح أن الإبتلاء - نسأل

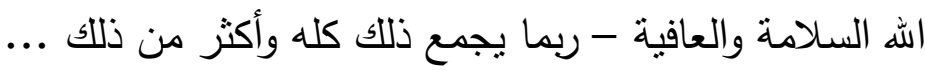

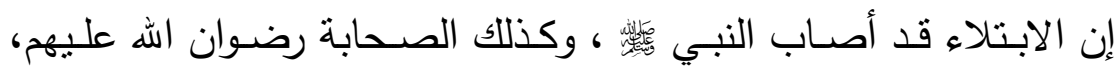

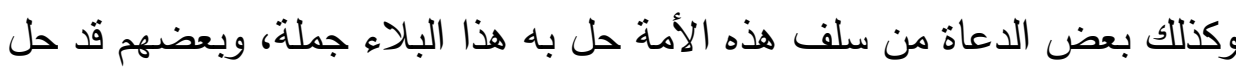
به جزء من هذا البلاء، فنسأل اله السلامة والعافية. وقد يبتلى الإنسان على قدر دينه ومقامه:

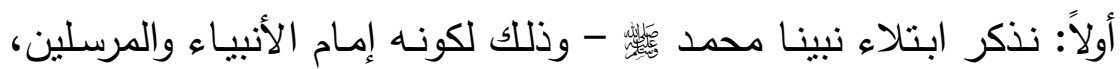

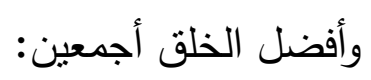

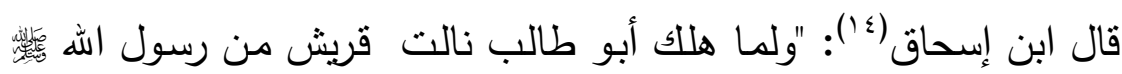

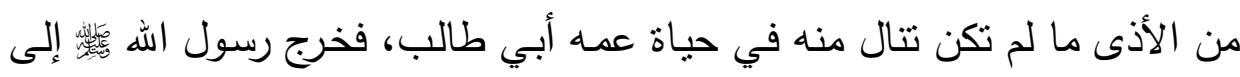

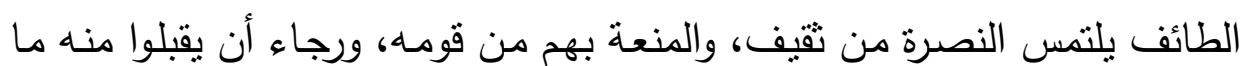
جاءهم به من الله عز وجل، فخرج إليهم وحده".

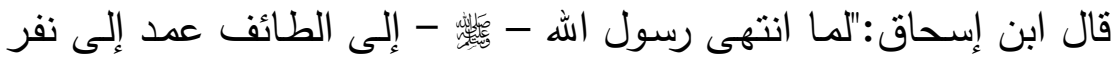

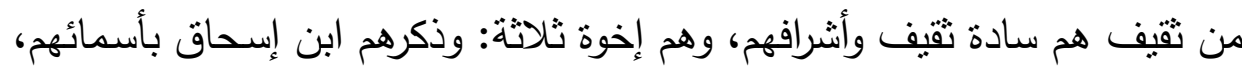
فجلس إليهم رسول اله

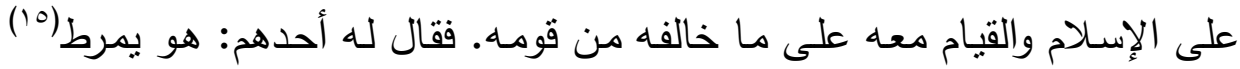

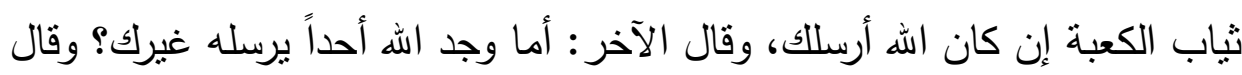

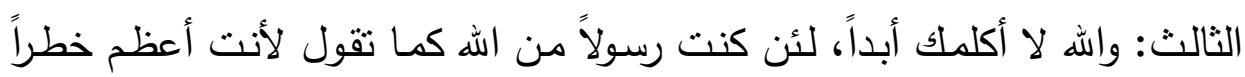

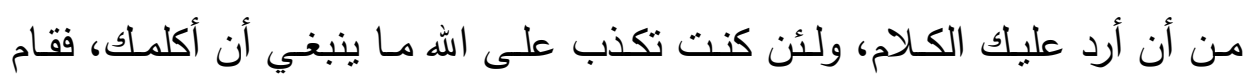


رسول الله - - من - من عندهم وقد بئس من خبر ثقيف، وقد قال لهم فيما ذكر لي

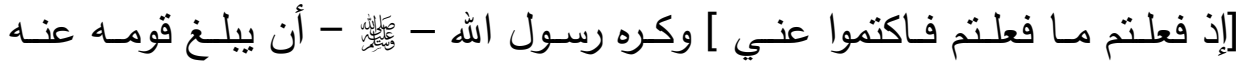
فيذئرهم (ج) ذلك عليه. فلم يفعلوا، وأغروا بـه سفاءهم وعبيدهم يسبونه ويصيحون به، حتى اجتمع عليه الناس، وألجأؤه إلى حائط لعتبة بن ربيعة وشيبة ابن ربيعة

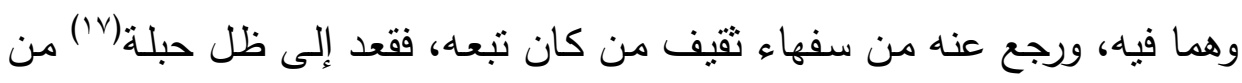
عنب فجلس فيه، وابنا ربيعة بنظران إليه ويريان ما لقى من سفهاء أهل الطائف. وقد لقي النبي لقينا من أحمائك" فلما أطمأن الرسول فئس قال فيما ذكر لي: " اللهم إليك أشكو ضعف قوتي وقلة حيلتي وهواني على الناس يا أرحم الراحمين أنت رب المستضعفين وأنت ربي إلى من تكلني؟ إلى بعيد يتجهني أم

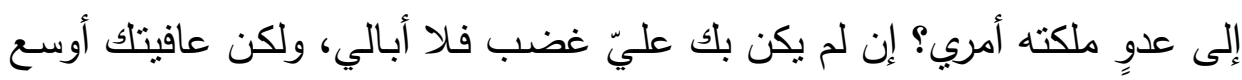
لي، أعوذ بنور وجهك الذي أشرقت لـه الظلمات وصلح له أمر الدنيا والآخرة من أن تتزل بي غضبك أو يحل عليّ سخطلك، لك العتبى(') حتى ترضسى، ولا حول

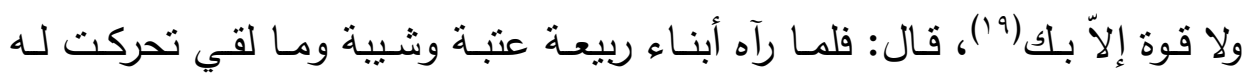

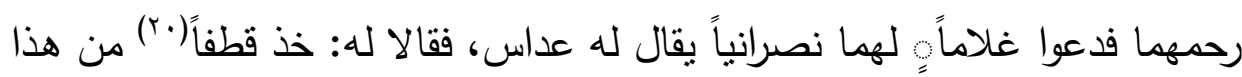
العنب فضـعه في الطبق ثم اذهب بـه إلى ذلك الرجل فقل لـه يأكل منـه، ففعل

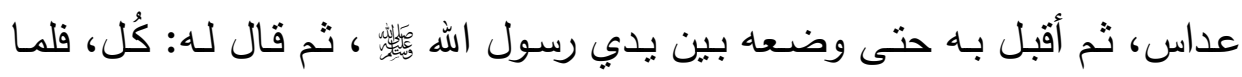

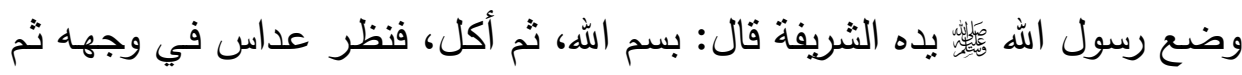

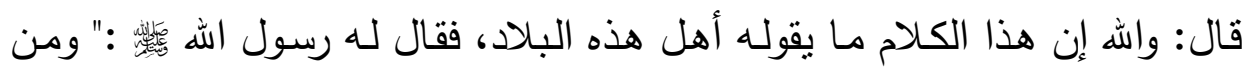
أهـل أبيّ البلاد أنـت يـا عداس؟ ومــا دينـلك؟" قـال: نصـراني وأنـا رجـل مـن أهـل

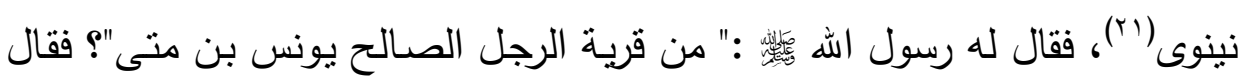

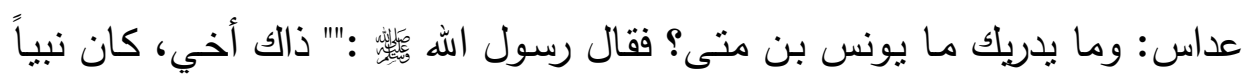

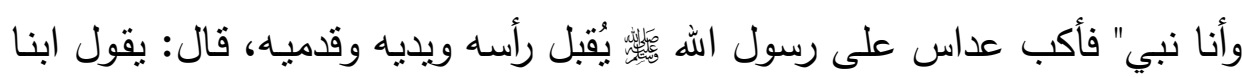


ربيعة أحدهما لصاحبه: أما غلامك فقد أفسده عليك، فلما جاءهما عداس قالا له: وبلك يا عداس!! مالك تقبل رأس هذا الرجل ويديه وقدميه؟ قال: يا سبدي ما في الأرض شيء خير من هذا، لقد أخبرني بأمرٍ ما بعلمه إلاّ نبي، قالا له: وبحك يا عداس!! لا يصرفنك عن دينك، فإن دينك خير من دينه.

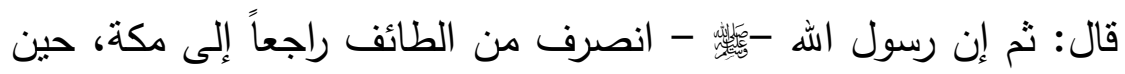
يئس من خبر ثقيف، حتى إذا كان بنخلة قام الليل يصلي، فمر به نفر من الجن الذين ذكرهم الله تبارك وتعالى ، وهم فيما ذكر لي - سبعة نفر من الجن أهل نصيبين، فاستمعوا له، فلما فرغ من صلاته ولّوّ إلى قومهم منذربن، قد آمنوا

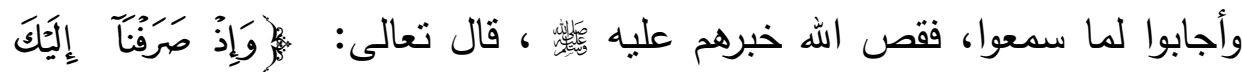

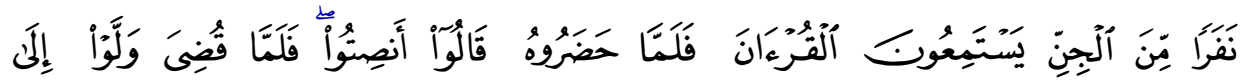

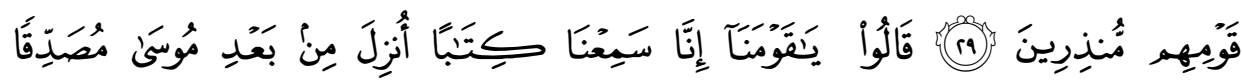

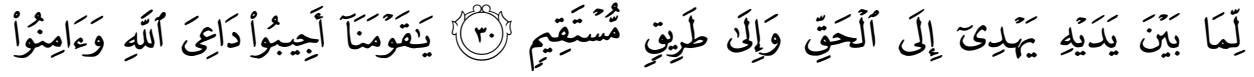

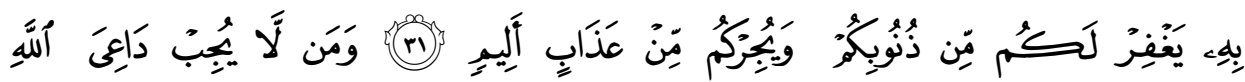

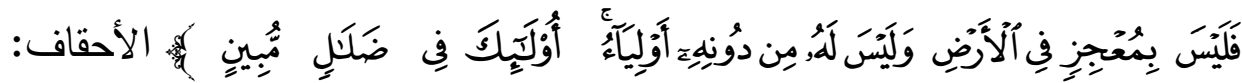

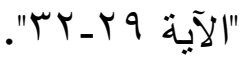

وقال تعالى:

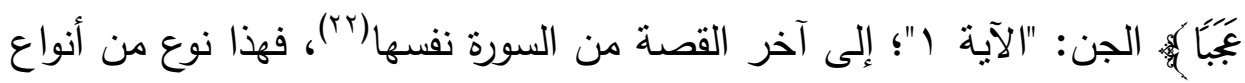

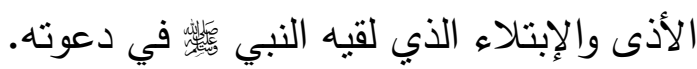

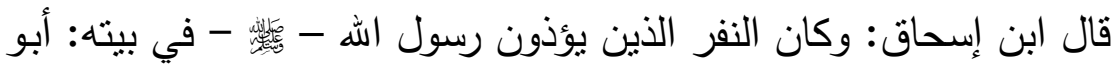
لهب، والحكم بن العاص بن أمية، وعقبة بن أبي معيط، وعدي بن حمراء الثقفي،

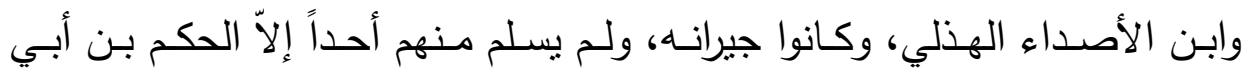

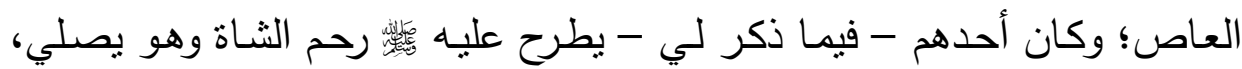




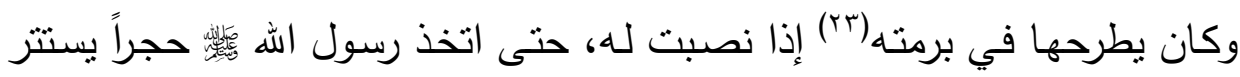
به منهم إذا صلى؛ فكان رسول الله الله ثم يلقيه في الطريق (ع ب).

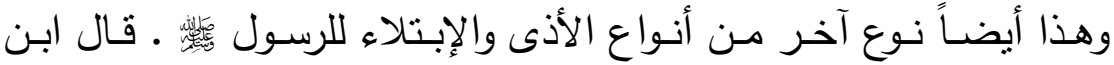
إسحاق رحمـه الله: فذكر لي أن أم جميل حمالة الحطب - حين سمعت مـا نزل

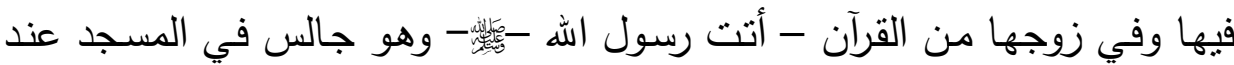

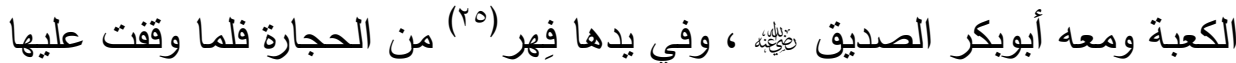
أخذ الهه ببصرها عن رسول الله أين صاحبك؟ فقد بلغني أنه يهجوني، والله لو وجدته لضربت بهذا الفهر فاه، أمسا

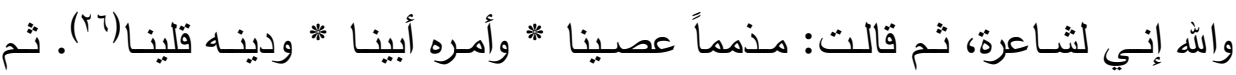
انصـرفت، فقال أبوبكر : يـا رسـول الله، أمـا رأتك؟ " فقال مـا رأتتي، لقد أخذ الله

$$
\text { ببصرها عني". }
$$

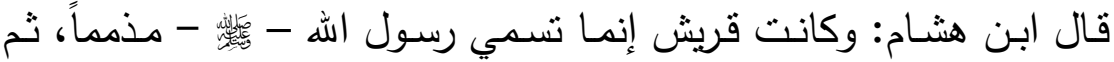

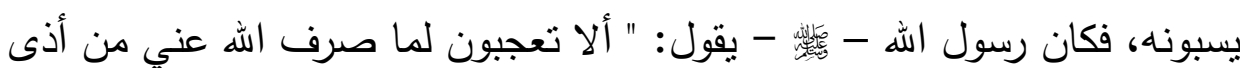

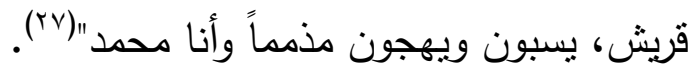

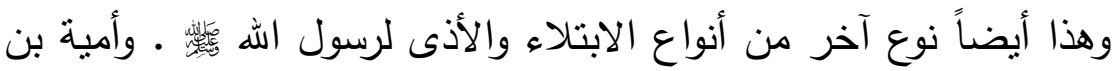

خلف بن وهب بن حذاقة بن جمح، كان إذا رأى رسول الله فأنزل الله تعالى فيه:

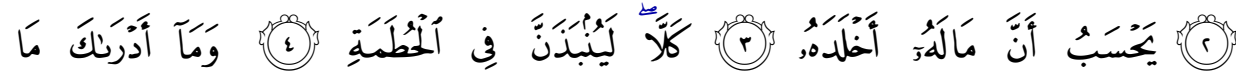

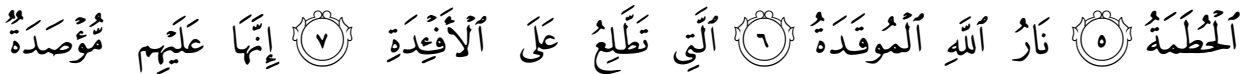

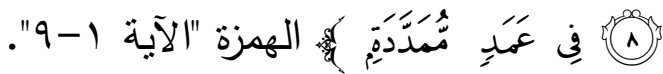


قال ابن هشـام: والهمزة: الذي يشتم الرجل علانيـة، ويكسر عينـه عليه،

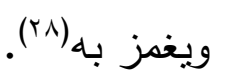

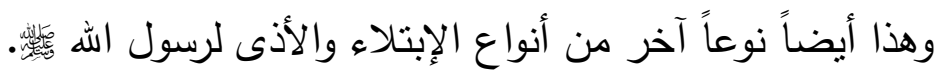

ثانياً: نذكر بعضاً من ابتلاء الأنبياء عليهم السلام وخاصة أولي العزم منهم:

والقرآن الكريم يحدثنا عما أصساب الأنبياء والمرسلين من الأذى والابتلاء

$$
\text { والاضطهاد. }
$$

فنـوح عليـه السـلام: تحمل الأذى والإبتلاء تسعمائة وخمسين عامـاً من قومه، وهم يزجرونه، ويقولون لله مجنون ويمرون عليه وهو يصنع الفلك فيسخرون منه ويستهزئون بـه، فلما ضاق بهم ذرعاً، وبلغ السيل الزبى دعا ربه قال تعالى :

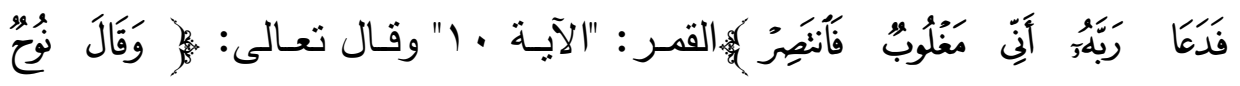

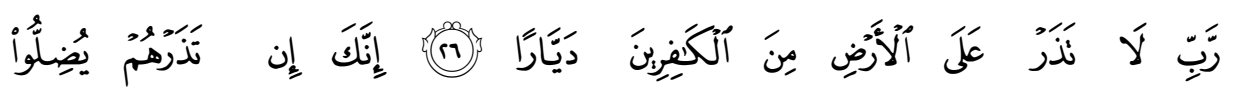

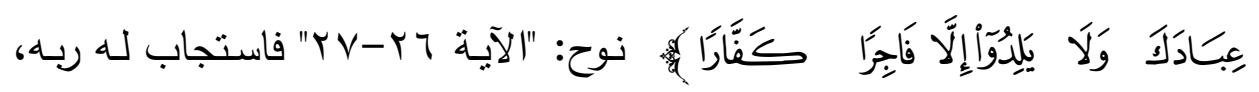

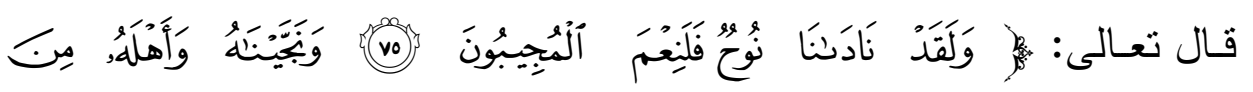

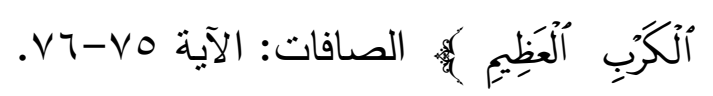

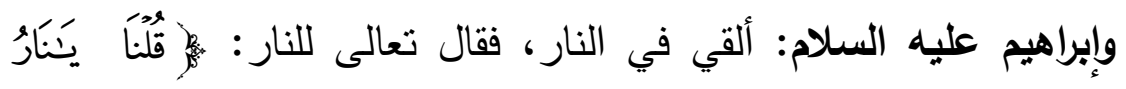

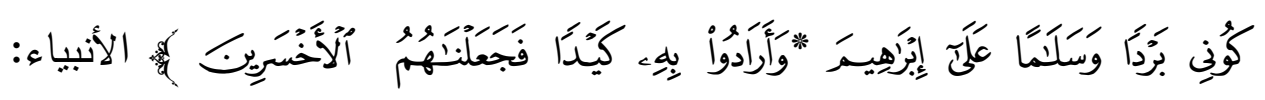

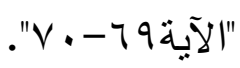

وموسى عليه السـلام: قد ابتلي وأوذي إيذاءً شديداً، فقال الله تعالى فيه:

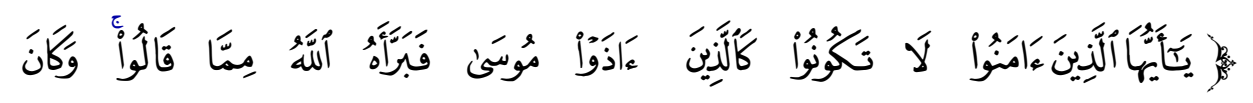

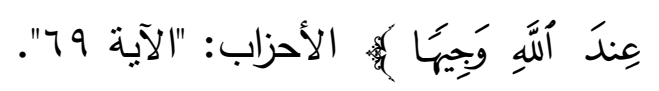




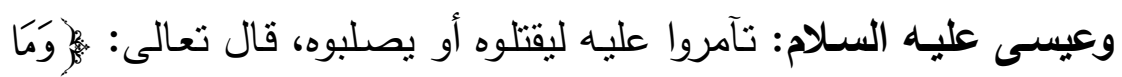

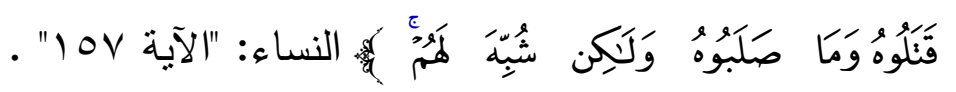

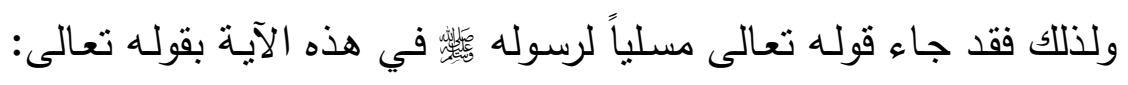

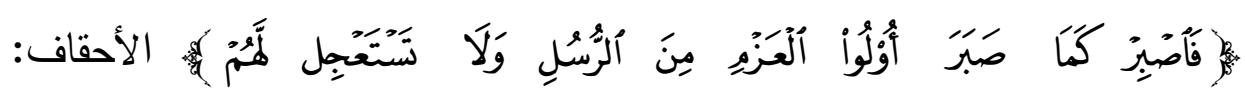

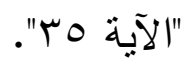

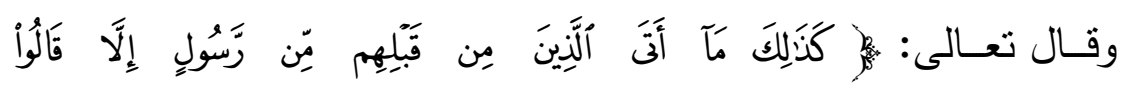

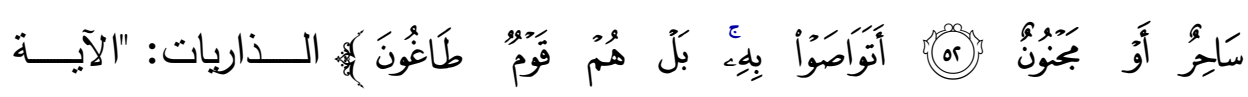
.

ثالثاً: نذكر بعض الصور من الإبتلاءات التي تعرض لها الصحابة رضي

الله عنهم:

المشهد الأول: بلال بن رياح رضي الله عنه: كان يعذبه أمية بن خلف على توحيده وإيمانه بالله تعالى واستجابته لدعوة

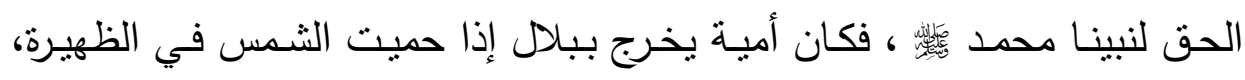
فيطرحسه على ظهره في بطحساء مكـة، ثم يـأمر بالصـخرة العظيمـة فتوضـع على

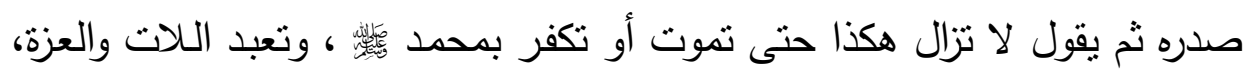

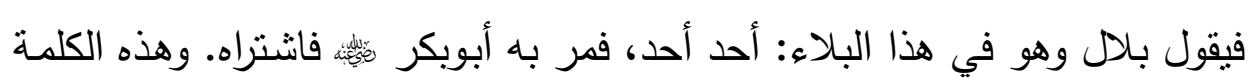

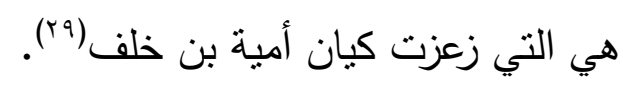
المشهد الثاني: من مشاهد الإبتلاء التي تعرض لها الصحابة رضي الله عنهم:

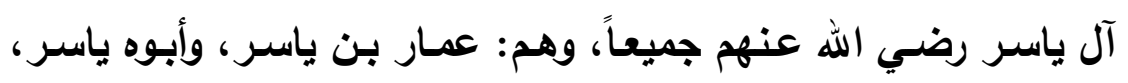
وأمه سمية: - n كانوا يعذبون أثند العذاب من أجل إيمـانهم بـالهه تعـالى، فلم يَرُرهَم ذلك العذاب عن دينهم شيئاً، وذلك لأنهم صدقوا الله فصدقهم اله تعالى، ولهذا قال لهم 
رســول الله

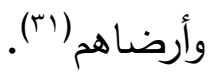

المشهد الثالث: من مشاهد الإبتلاء والأذى: عبدالله بن حذاقة بن قيس رضي الله عنه:

عندما حساول ملـك الـروم أن يصـده عـن دينـهـ - يـرى الداعيـة الموقف لفه

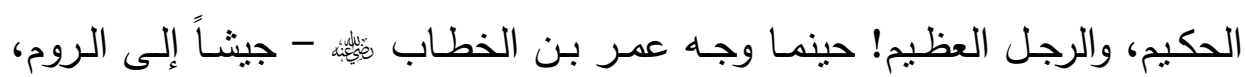
فأسروا عبداله بن حذاقة، فذهبوا به إلى ملكهم، فقالوا: إن هذا من أصحاب محمد

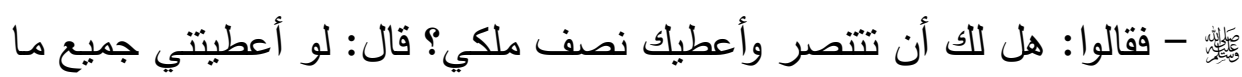

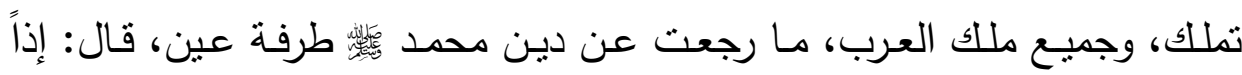
أقتلك.

قال: أنت وذاك، فأمر بـه فصلب وقال للرماة أرموه قريباً من بدنه، وهو يعرض عليه ويأبى ولم يجزع، فأنزله. وأمر بقدر فصب فيه ماء وأغلي عليه حتى احترقت، ودعا بأسيرين من المسلمين فأمر بأحدهما، فألقي فيها فإذا عظامه تلوح، فأمر بالثاني، فألقي فيها فإذا عظامه تلوح، وهو يعرض عليه النصرانية وهو يأبى،

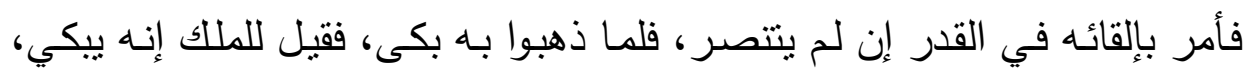
فظن أنـه جزع، فقال: ردوه، فقال: مـا أبكالك؟ قال: قلت هي نفس واحدة تلقى الساعة فتذهب، فكنت أثتهي أن تكون بعدد شعري أنفس تلقى في النار في الله تعـالى، فتعجب الطاغيـة، فقال لـه: هـل لك أن تقبـل رأسـي وأخلي عنـك؟ فقـال عبداله: وعن جميـع أسـارى المسلمين؟ قال: نعم، فقبـل رأسـه فخلى عنهم، وقدم بالأسرى على عمر هِئزهُ ، فأخبره خبره، فقال عمر : حق على كل مسلم أن يقبل

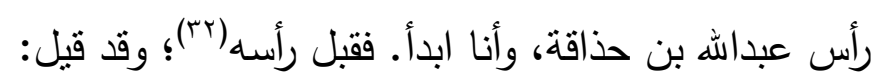

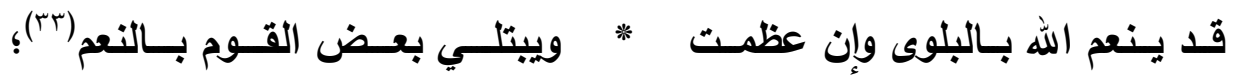




\section{المبحث الثالث \\ الحكمة من الإبتلاعات}

لاشك أن الإبتلاء يكون أحياناً تمحيصاً، وقد سبق لنا ذكر ذلك، وأحياناً يكون لأجل رفع منزلة ودرجة صاحبه في عليين في الجنة، كما جاء في الحديث، عن إبراهيم بن مهدي السلمي، عن أبيه، عن جده(ء)، وكانت له صحبه مع رسول

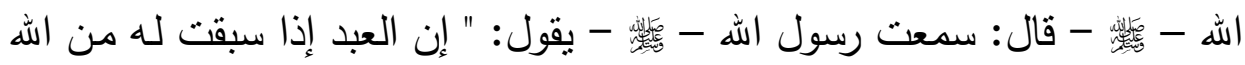
منزلة لم يبلغها بعمله ابتلاه الله في جسده، أو في ماله، أو في ولده" قال أبوداؤد: زاد ابن نفيل "ثم صبر على ذلك" ثم اتفقا" حتى يُبِلِفه المنزلة التي سبقت له من الله

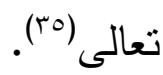
وأحياناً يكون من أمر الله المقدر على عباده كما جاء في قوله تعالى:

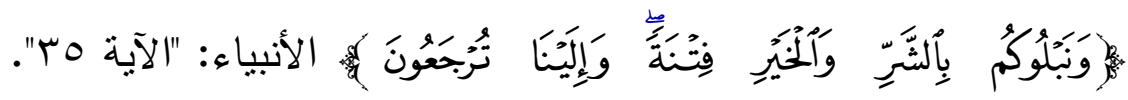

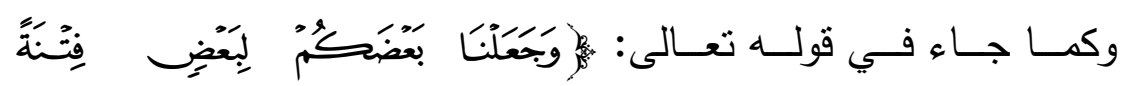

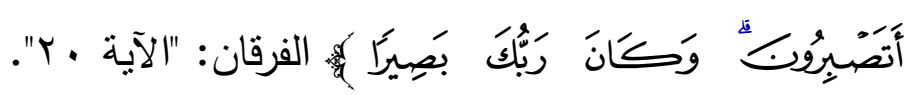

وقولـه:

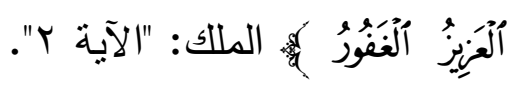

وقولــاه: بَصِيرًا بم: الإنسان: "الآية r".

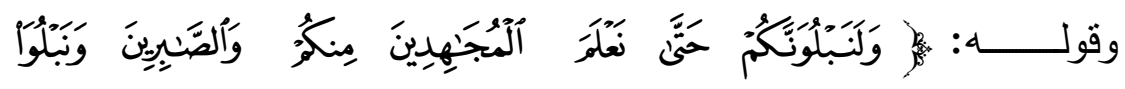

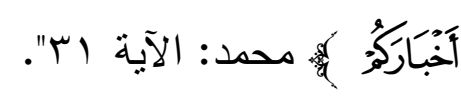




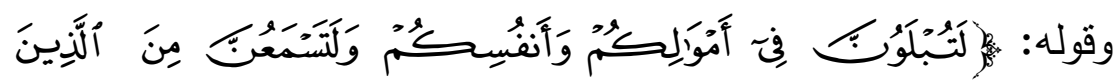

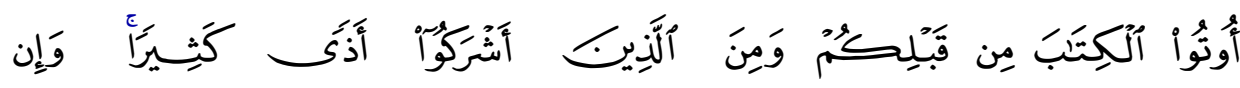

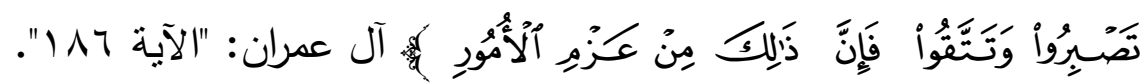

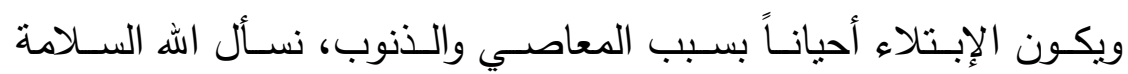

$$
\text { والعافية، كما جاء في قوله تعالى: }
$$

مَإِ

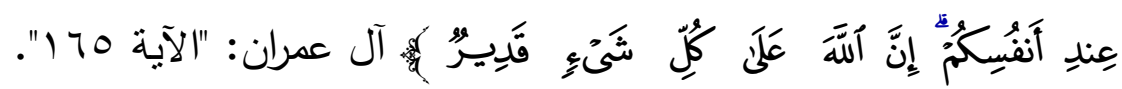

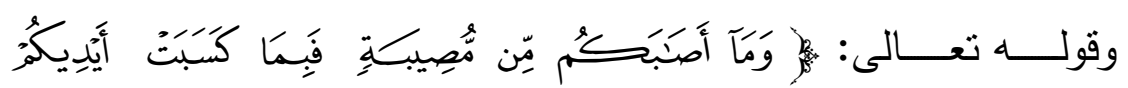

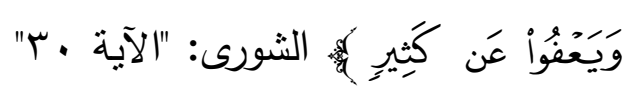

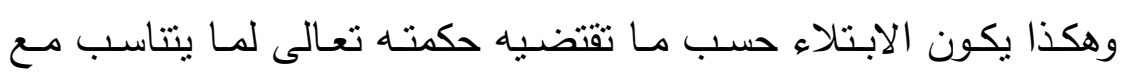

$$
\text { مراتب البشر وحسب أحوالهم. }
$$

ولنذكر منالاً واحداً لسحرة فرعون المؤمنين، وسبب ما حل بهم من البلاء

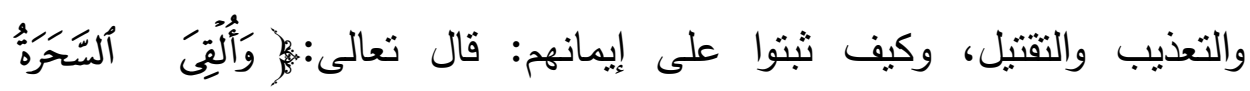

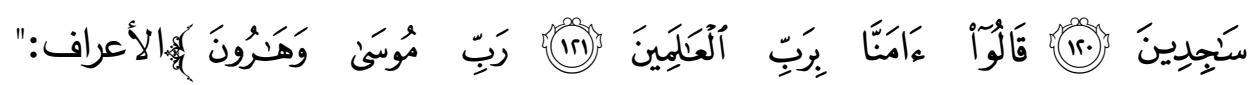

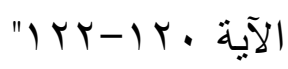

السحرة الذين عرفوا الحق فآمنوا وصدقوا به، هم أكثر من لقي صنوفاً من

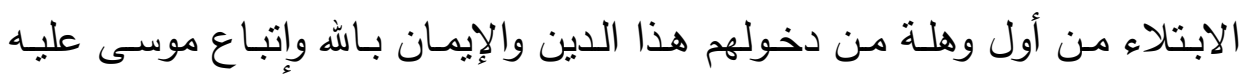

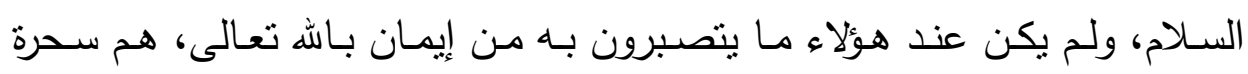

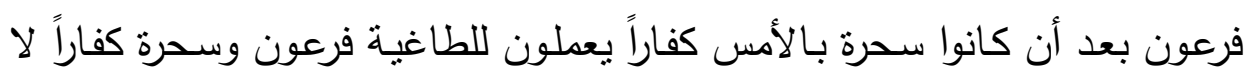

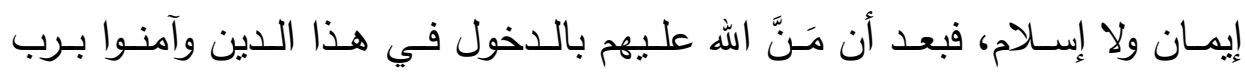

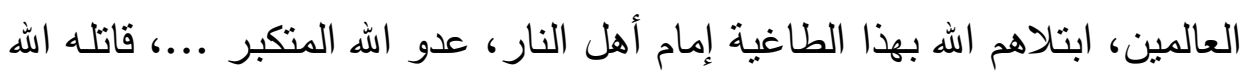

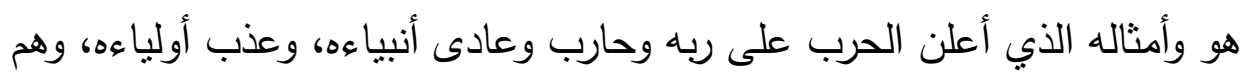


[هؤلاء السحرة الذين كانوا معه بالأمس الذي تحداهم وقبل أن يتحداهم تحدي اله رب العالمين بإدعائه الربوية] بأن قال، كما أخبر الله تعالى عنه في كتابه العزيز :

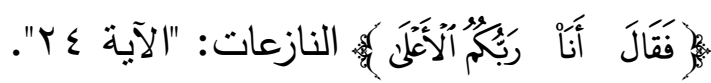
وسبق لله أن تحدى موسىى عليه السـلام بأن قال لـه، كما أخبر تعـالى عنه:

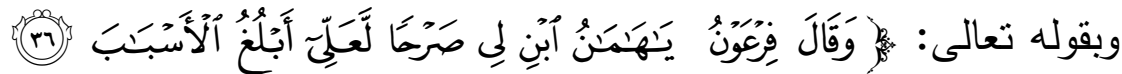

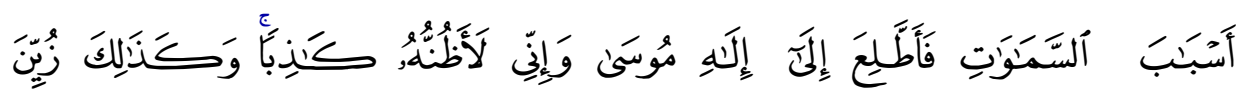

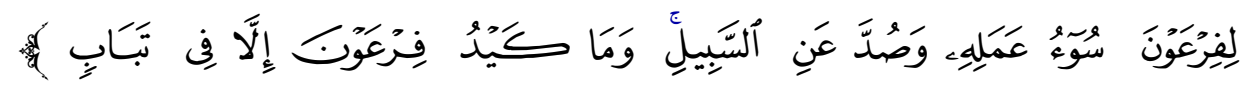

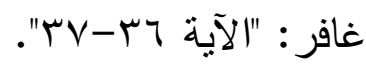
وهكذا يأتي البلاء للاعاة أحياناً لتمحيصهم، أو لمحبة الله لهم جل جلاله،

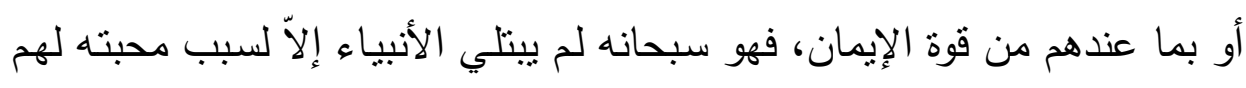
ولقوة إيمانهم •

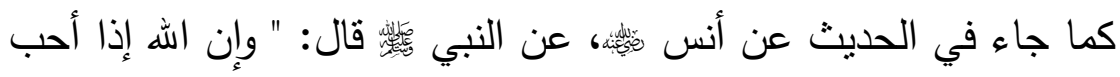

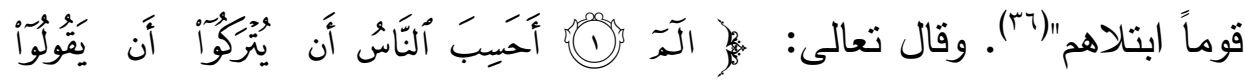

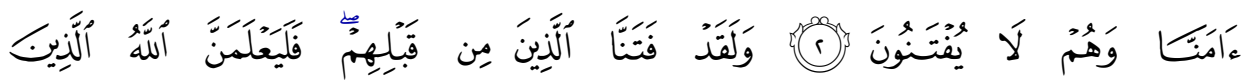

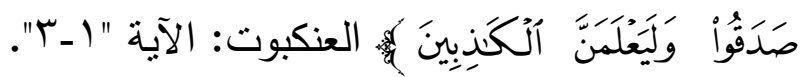

ذكر أهـل التفسير رحمهم الله في تفسير هذه الآيـة أن هنالك اسـتفهام إنكار، ومعناه أن الله سبحانه وتعالى يبتلي عباده المؤمنين بحسب ما عندهم من

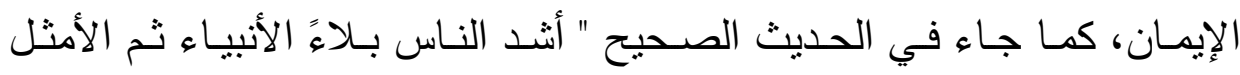
فالأمثل، ويبتلي الرجل على قدر دينه فإن كان في دينه صـابة زيد لله في البلاء (rv)" 
فهذا دليـل على ابـتلاء العبـاد حتى يميزز الله الخبيـث مـن الطيب، قـال

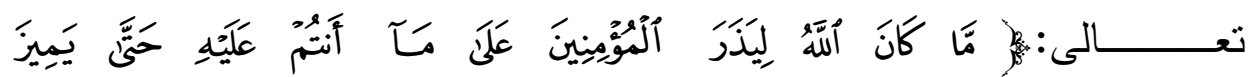

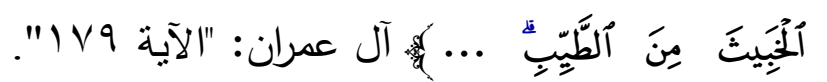

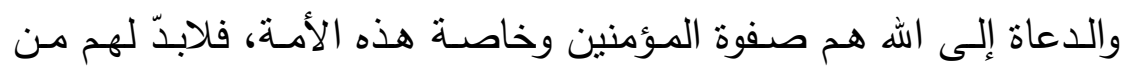
التمحيص والابتلاء حتى يثبتوا على الطريق ويصدقوا مع الله تعالى في دعوتهم. 


\section{المبحث الرابع}

الصبر على الابتلاءات

تعريف الصبر:

الصبر لغـة: حبس النفس عن الجزع وبابه ضرب و [صَبَرَهُ] حبسـه، قال

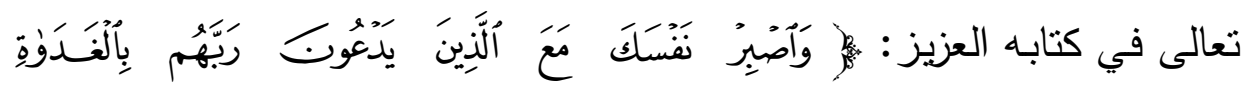

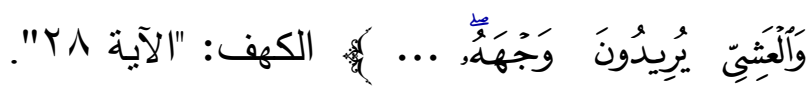

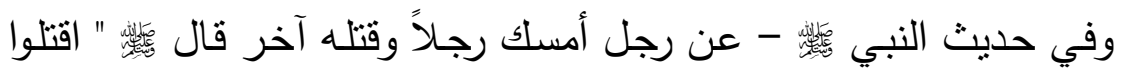

القاتل، واصبروا الصابر "(م^) أيّ احبسوا الذي حبسه للموت حتى يموت.

الصـبر شـرعاً: حبس النفس عن الجزع والتسـخط، وحبس اللسـان عن احن

الثنكوى، وحبس الجوارح عن التشويش. وقيل: الصبر الوقوف مـع البلاء بحسن

الأدب. وقيل هو الفناء في البلوى، بـلا ظهور ولا شكوى. وقيل هو تعويد النفس

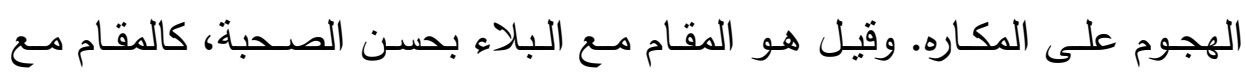

العافية.

وقيل: الصبر صبران؛ [فصبر عند المصيبة حَسنَ جميل، والصبر على

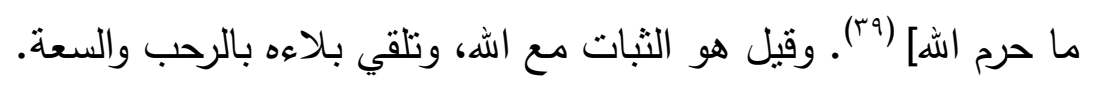

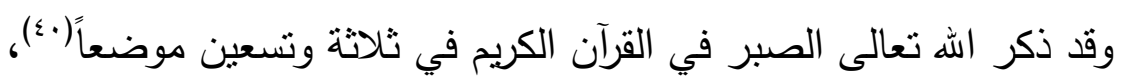
وأضاف إليه أكثر الخيرات والدرجات وجعلها ثمرة له.

\section{والصبر ثلاثة أنواع:}

1- صبر على طاعة الله.

r- صبر على معصية الله.

ب- صبر على امتحان الهه [الابتلاءع]

وهذا الأخير هو موضوع بحثنا. 
وهنا وقفة لابدّ منها وهي من الأهمية بمكان، والدعاة إلى الله تعالى في حاجة ماسة لها، ألا وهي:

يتعرض الدعاة إلى الله إلى معارضـة ومجادلة، وصدّ وجحود، ومنع من أدائهم وقيامهم بواجبهم الدعوي. وأمام ضغوط الواقع القائم اليوم، والعقبات والمحن التي تأتيهم من حيث لم يحتسبوا، وما لم يكن في بالهم وخاطرهم، ففي مثل هذه الأمور ، يحتاج الداعية إلى صبر ، أقول بل يحتاج إلى الصبر الجمبل؛ كما جاء

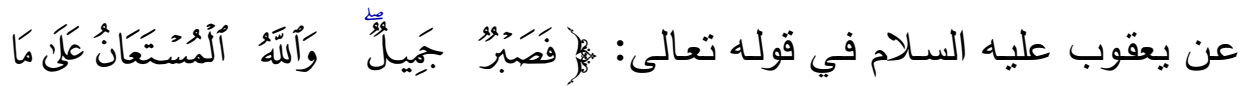

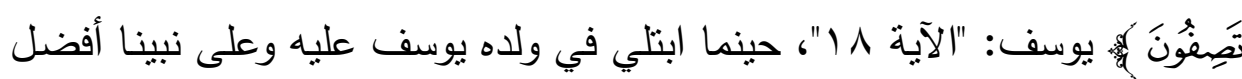
الصحلاة وأثم السلام.

إن المـؤمن الحـق، يعلـم أن الصـبر قـوة نفسية إيجابيـة فعالـة ... تـدفع المتحلي بـه إلى مقاومـة كل أسباب الخور ، والضـف، والاستكانة، والاستشـلام، والانهزامية المقيتة ... وتحمله على الصدود والثبات أمام الفتن والمغريات، وأمام المحن والمكاره والأحداث ...إلى أن يأذن الله بالنصر ، أو أن يلقى الله عز وجل واله وله وهو عنه راض ...

وعلـى الداعيـة حسين يبــن دعـوة الله أن يضــع في حسبانه هـــه

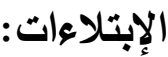

ا ـ الاتهامـات الكاذبة، والأقاويل الباطلة للحط من شـأنه، والتقليل من مكانه

$$
\text { واعتباره. }
$$

r. السجن والاعتقال والتعذيب ... وكل اعتداء يمسه مادياً ويصيبه جسدياً... r. إخراجه من وظائفه، ومصادرة أملاكه، واقتطاع كسبه ورزقه. ء. تهجيره من بلده، ومفارقته لأهله وأولاده، وابتعاده عن أصدقائه وأحبابه. ه. إغراؤه بالمنصب والوظيفة، وفتتنه بالمال والجاه، واغواؤه بالجنس والنساء وقد يلبس هذا الإغواء ثوب الزواج في كثير من الأحيان. 
7. وأخيراً أن يضع في حسبانه الاستشهاد والثهادة في سبيل الله والدعوة إليه

$$
\text { تبارك وتعالى. }
$$

فحين يضع الداعية نصب عينيه كل هذه الاحتمالات وغيرها من ضروب

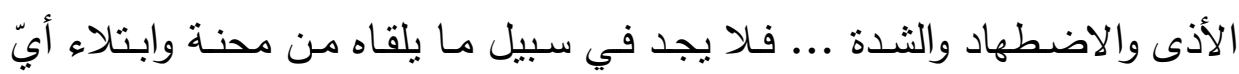
حـرج أو غضاضــة أو بـأس أو انهزاميـة ... لأن مـن طبيعـة الـدعاة الصـادقين،

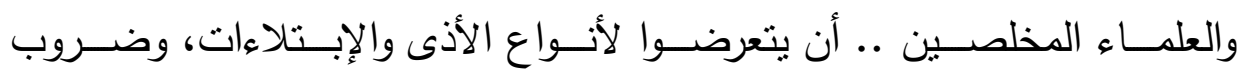
الاضطهاد .. وحسبهم في ذلك: قدوتهم وقائد دعوتهم، ورائد رسالتهم محمد بن عبداله

فإنه به في الصبر والاحتمال، والأسوة الحسنة في الصمود والتبات ... فإن المشركين في

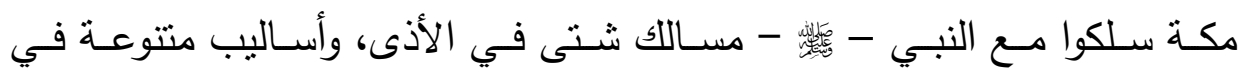
الاضطهاد .. ليصدوه عن دعوته، ويثثوه عن أداء رسالته، فما استكان ولا تأثز صلوات الله وسلامه عليه. 


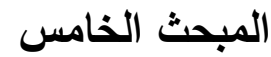 \\ الأجر المترتب على الإبتلاءات}

اعلم أخي المسلم أن عاقبـة البلاء حميدة للمؤمن، وعائدة عليه بـالخير ، إندير كما قال تعالى:

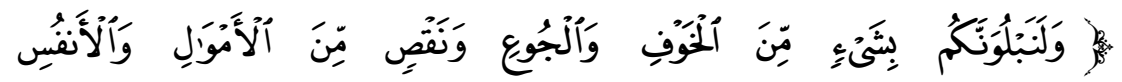

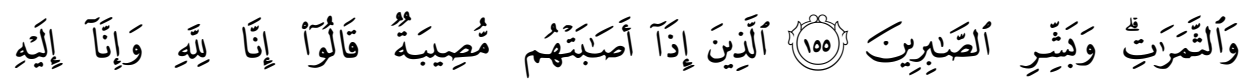

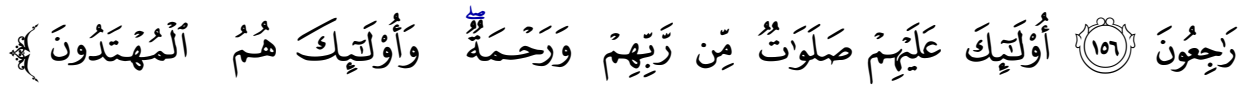

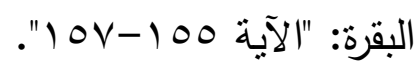
وقال تعالى :

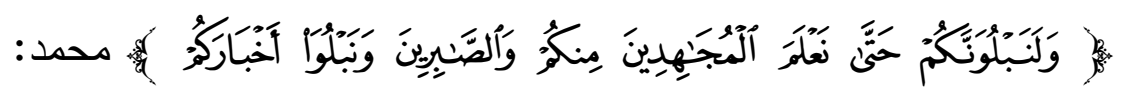

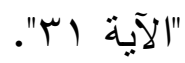

ذكر الثوكاني رحمه الله في تقسيره: أبيّ لنعاملكم معاملة المختبر ، وذلك بأن نأمركم بالجهاد حتى نعلم من امتثل الأمر بالجهاد وصبر على دينه ومشاق

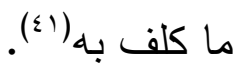

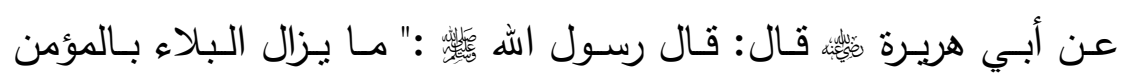
والمؤمنة في نفسه، وولده، وماله، حتى يلقى الله تعالى، وما عليه خطيئة"(ז؛).

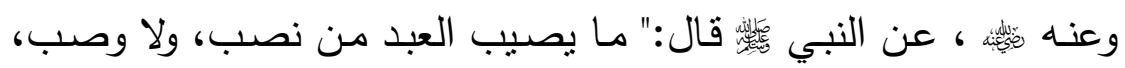
ولا هـ، ولا حزن، ولا أذى، ولا غم، حتى الثـوكة يشـاكها، إلاّ كفر الله بهـا مـن

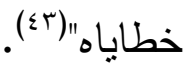

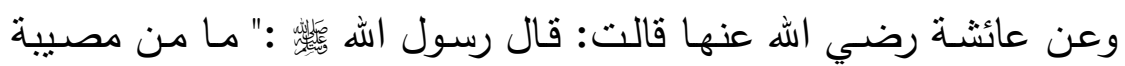
تصيب المسلم، إلاّ كفر الله بها عنه، حتى الثوكة يشاكها"(؟؛). 


\section{ألا وأن الإبتلاء دليل على محبة الله لعبده:}

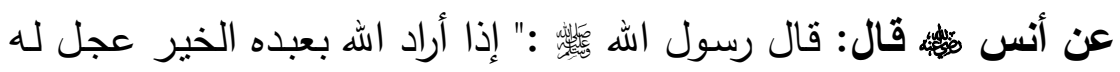
العقوبـة في الـدنيا، وإذا أراد بعبـده الثـر أمسـك عنـه بذنبـهـ حتى بـوافي بـهـ يـوم

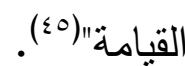

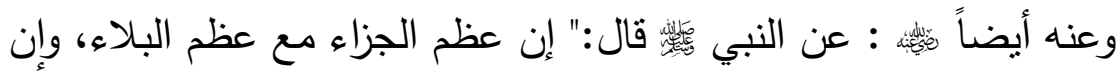

الله إذا أحب قوماً ابتلاهم، فمن رضي فله الرضى، ومن سخط فله السخط"(آ؛).

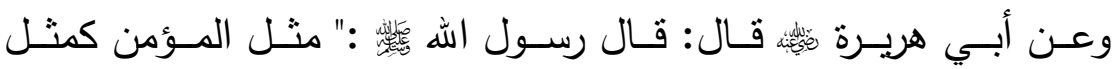
الخامـة(گ) من الزرع: من حيث أتتها الريح كفأتها، فـإذا اعتدلت تكفأ بـالبلاء.

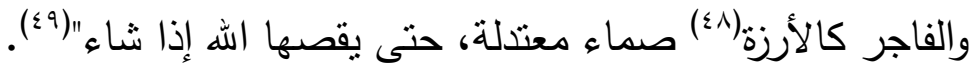




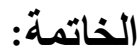

أولاً: النتائج:

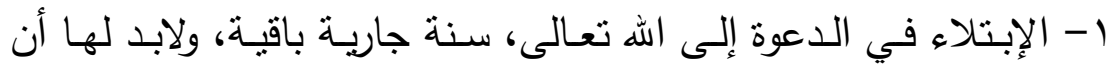

تجري بين العباد المجرى الطبيعي، فلا يجزع ولا يهلع لذللك الدعاة.

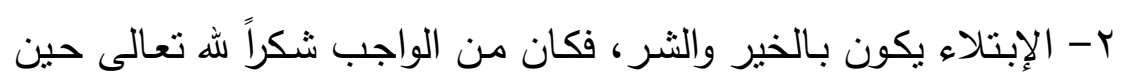

نزول الأولى، والصبر الصبر عند حلول الثانية.

r- الدعوة إلى الله تعالى محفوفة بالثدائد والدحن والمكاره.

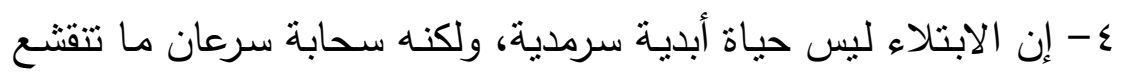

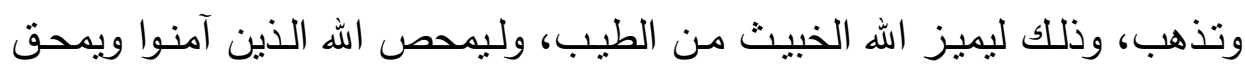

الكافرين

ه- إن بلوغ الغايات، والوصول إلى النهايات، لابد له من تكبد المصائب

والمتاعب والإبتلاءات، ولابد له من حصول العقبات ونزول الملمات.

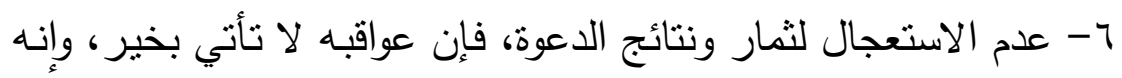

آفة ومرض يفتلك بالدعاة.

ثانياً: التوصيات:

1- أوصي نفسي وإخـواني الدعاة إلى الله تعالى بـالإخلاص في القول

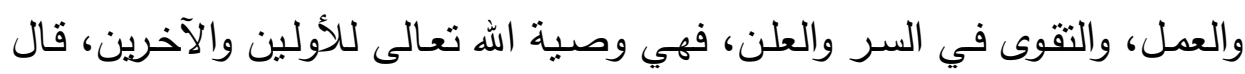

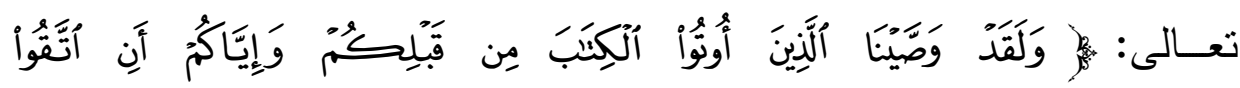

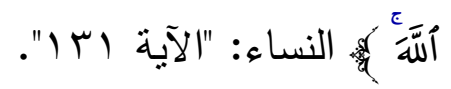

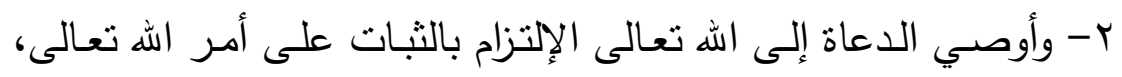

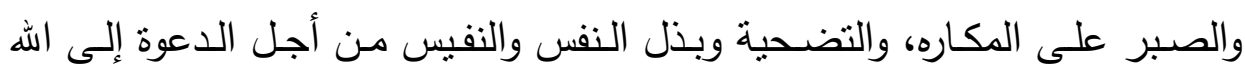

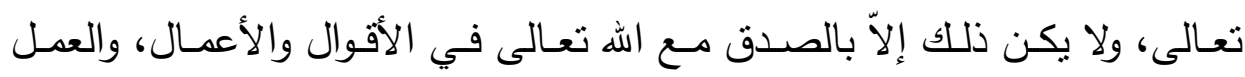

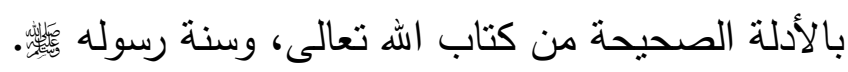


ب-على الدعاة أن يعزموا كل العزم على المضـي قدماً لمـا أمرهم الله بـه من الصبر والاحتساب عند الابتلاء والأذى في سبيل ذلك.

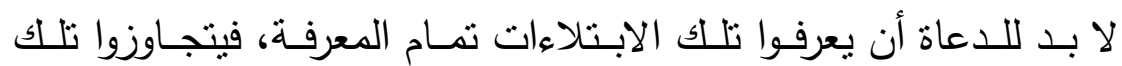

$$
\begin{aligned}
& \text { المحن، ويصبروا على ما فيها من الثدائد والمكاره. } \\
& \text { وآخر دعوانا أن الحمد لله رب العالمين. }
\end{aligned}
$$




$$
\begin{aligned}
& \text { (1) مختار الصحاح للشيخ الإمام محد بن أبي بكر بن عبد القادر الرازي: صح؟r. }
\end{aligned}
$$

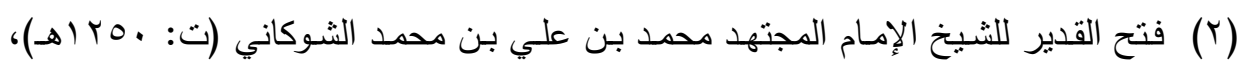

$$
\begin{aligned}
& \text {. r) } / 0 \\
& \text { (r) تقسير القرآن العظيم للإمـام الجليل عمـاد الدين أبو الفداء إسـماعيل بـن كثير القرشي عاني }
\end{aligned}
$$

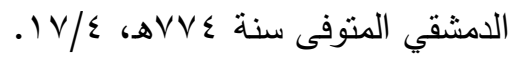

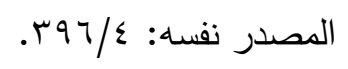

$$
\begin{aligned}
& \text { مصعب بن سعد بن أبي وقاص الزهري، أبو زرارة، ثقة، من الثالثة، مات سنة (ب ـ ( )هـ، }
\end{aligned}
$$

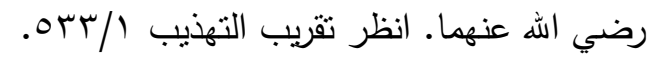

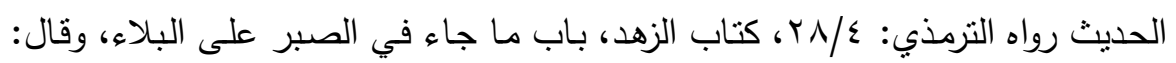

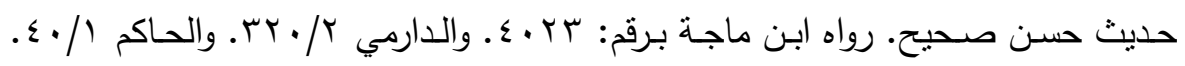

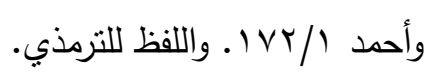

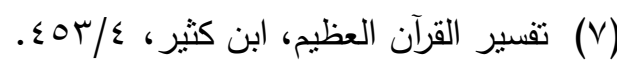

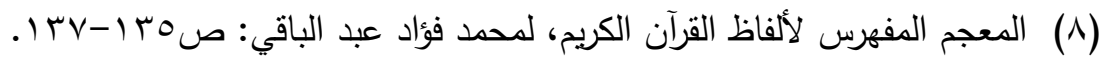

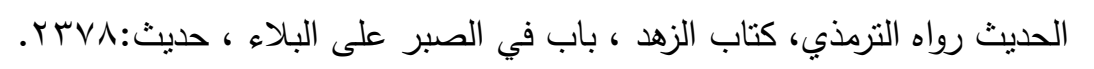

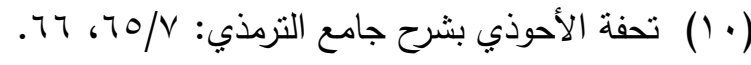

$$
\begin{aligned}
& \text { (1) الفضيل هو ابن عياض إمام التابعين رحمة الله عليه. }
\end{aligned}
$$

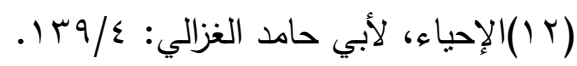

$$
\begin{aligned}
& \text { (T (IT) مسند أحمد بن حنبل، ومن مسند بني هاشم، مسند أبي سعيد الخدري رضي اله عنه - }
\end{aligned}
$$$$
\text { حديث:1) }
$$

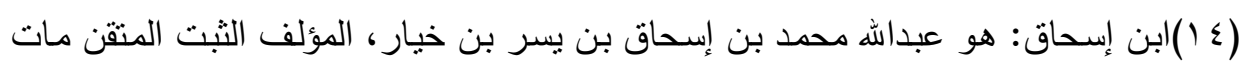

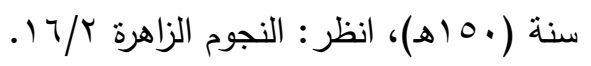

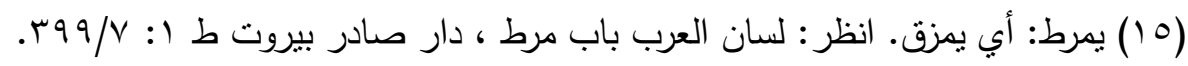$$
\text { (7 (1) يذئرهم: أي يحرش بينهم. أنظر لسان العرب، مرجع سابق. }
$$

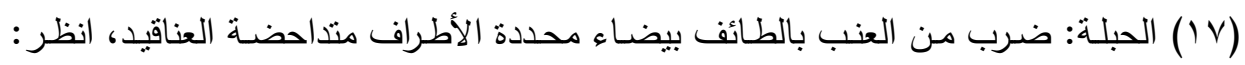

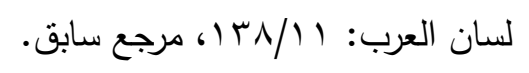




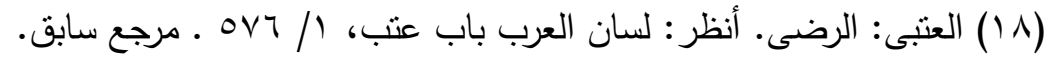

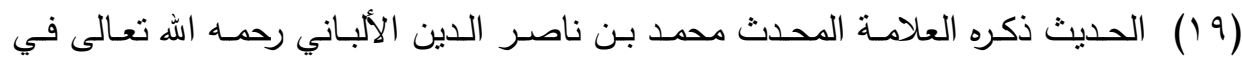

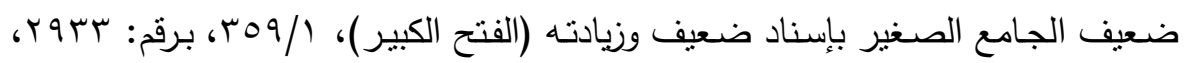

$$
\text { (بلسلة الأحاديث الضعيفة). }
$$$$
\text { (Y.) }
$$

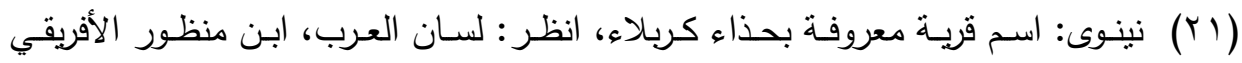

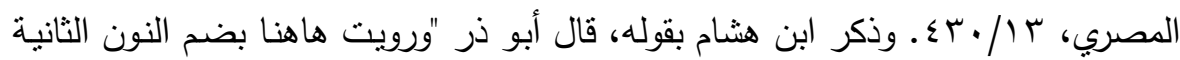
وبفتحها أنشهر هكذا ذكرها ابن هثام في سيرته". (Yr)

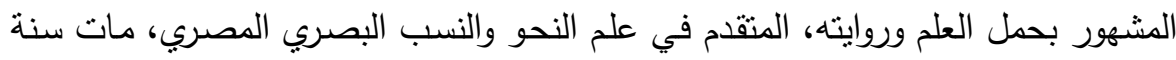

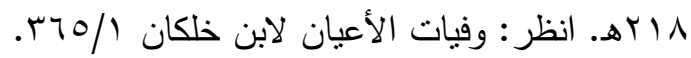

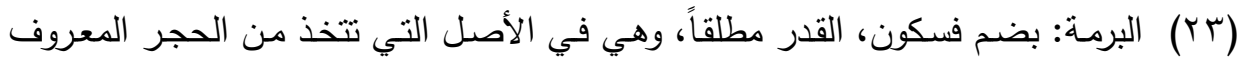

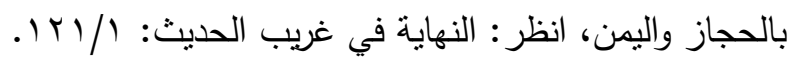

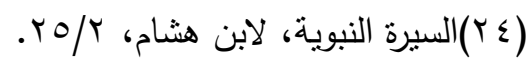

(Y0) الفهر : بكسـر فسكون، حجر على مقدار ملـئ الكف، النهايـة في غريـب الحـديث: $. \Sigma \wedge) / r$ (Y (Y) قلينا: أبغضنا، انظر : السيرة النبوية، لابن هثام، مصدر سابق.

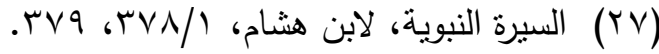

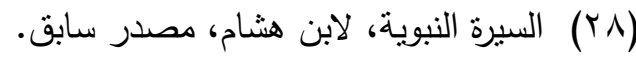

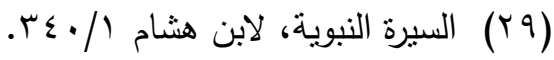

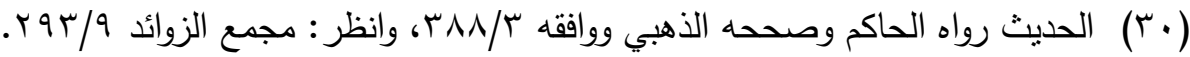

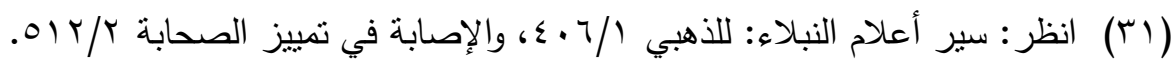

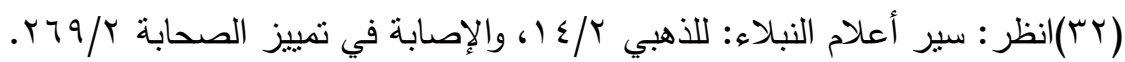

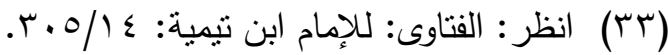

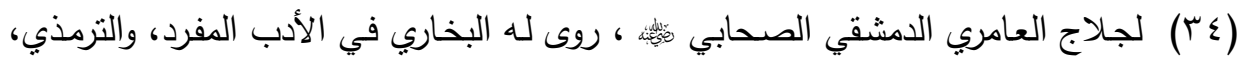

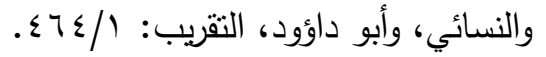


(ro) الحديث رواه أبو داؤود بسند صحيح. باب ما جاء في الصبر على البلاء، سبق ذكره.

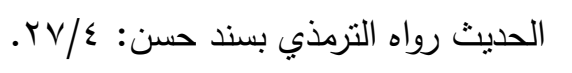

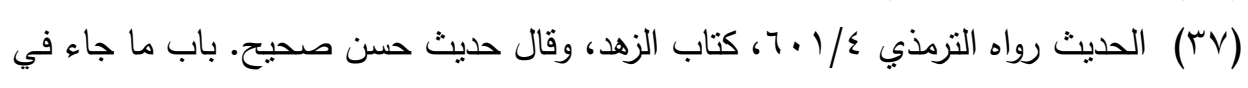

الصبر على البلاء، سبق ذكره.

( السنن الكبرى للبيهقي ، كتاب النفقات، باب الرجل يحبس الرجل للآخر فيقتله،

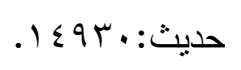

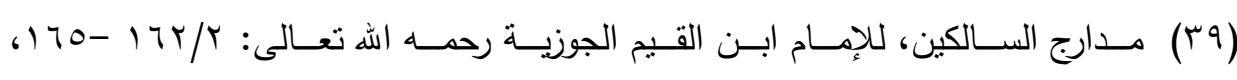

$$
\text { (بتصرف) ( المعحم) (1) }
$$

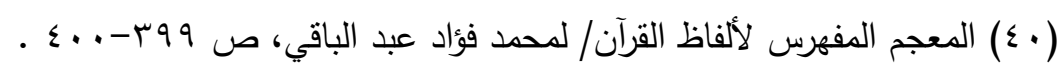

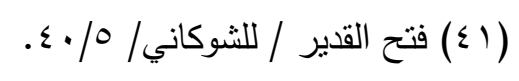

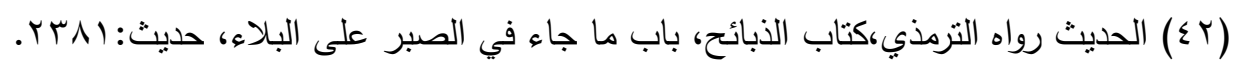

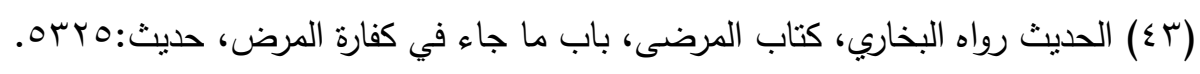

( ع §) الحديث رواه البخاري، نفس المصدر السابق.

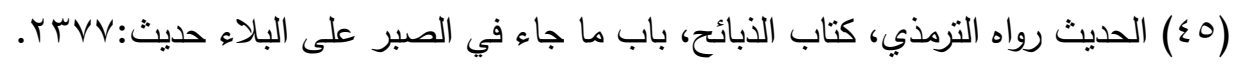

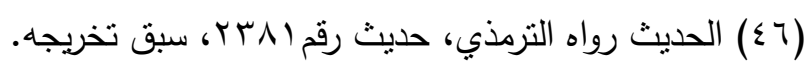

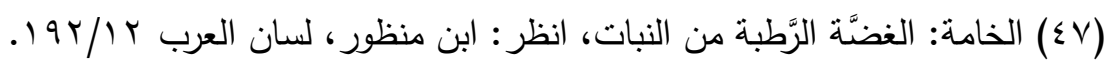

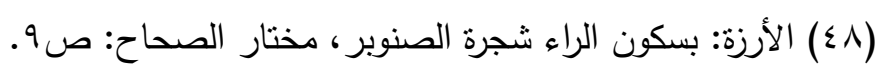

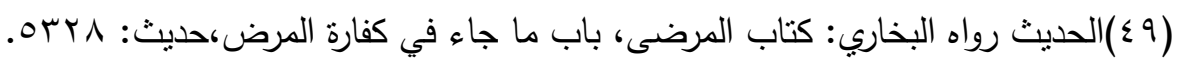


المصادر والمراجع:

الرقم

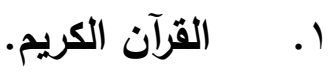

r. الإصـابة في تمييز الصحابة، لابن الفضل أحمد بن علي بن حجر الصر

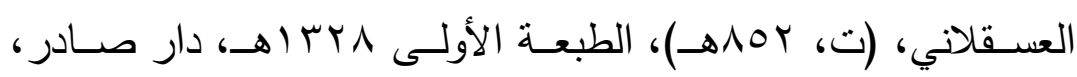

بيروت.

r. البدايـة والنهايـة، للحافظ أبي الفداء إسماعيل بن كثير، (ت، ع ع هـ)

الطبعة الثالثة، 9V9 (م، مكتبة المعارف، بيروت، لبنان.

ء. تحفة الأحوذي بشرح جامع الترمذي، لأبي العلى محمد بن عبدالرحمن

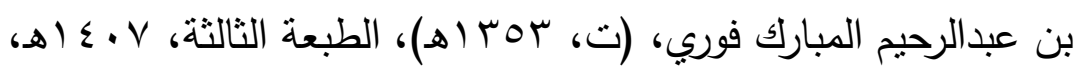

مكتبة ابن تيمية، القاهرة.

ه. تفسير القرآن العظيم، لأبي الفداء إسماعيل بن كثير القرشي، (ت، (تهره

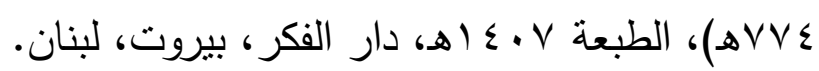

7. حيـاة الصـحابة، للثـيخ محمـد يوسـف الكانـد هلـوي، الطبعـة الثانيـة

r • ( اهـ، دار القلم، دمشق.

V. الرحيـق المختـوم، صـي الرحمن المبـارك فوري، الطبعـة جوب اهـ،

مكتبة دار السلام، الرياض.

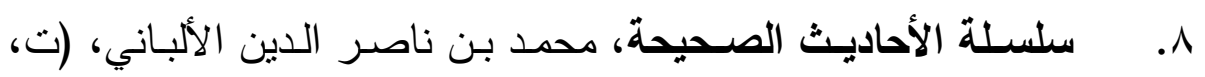

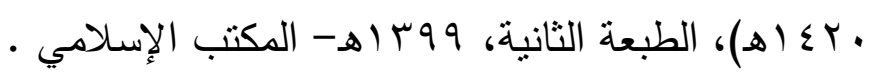

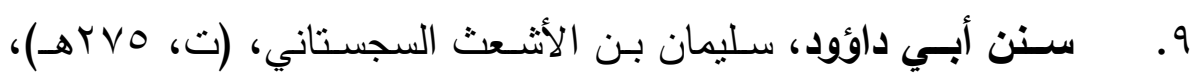

تحقيق محمد محي الدين عبدالحميد، بدون تاريخ، دار الفكر .

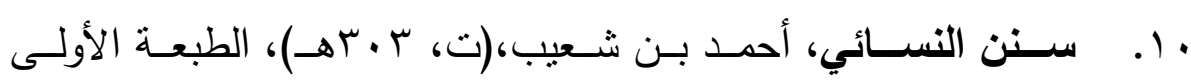

. (ه) 


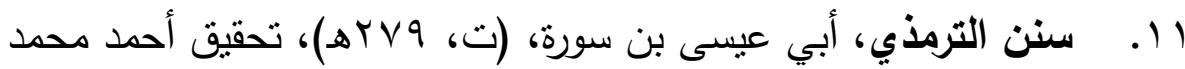

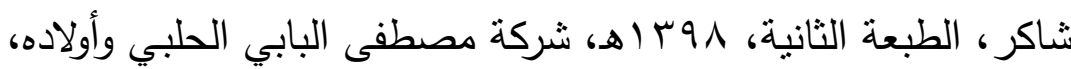
مصر -

Y I. سنن ابن ماجة، محمد بن بزيد القزوبني، (ت، فؤاد عبدالباقي، بدون ناريخ، دار إحياء التراثي العربي. با ا. سير أعلام النبلاء، شمس الدين محمد بن أحمد بن عثمان الذهبي، ت

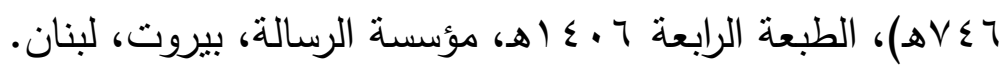

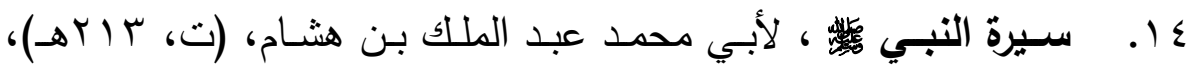
راجعـه وضـبطه محسي الـدين عبدالحميـد، بـدون تـاريخ، دار الكتب

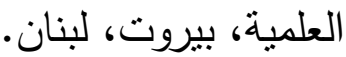

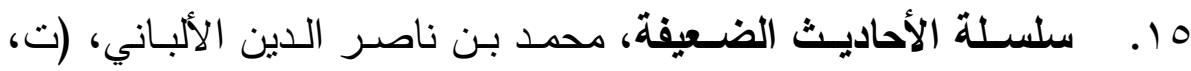

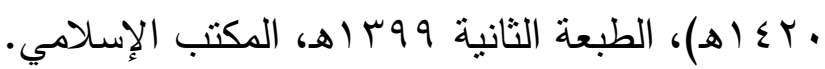

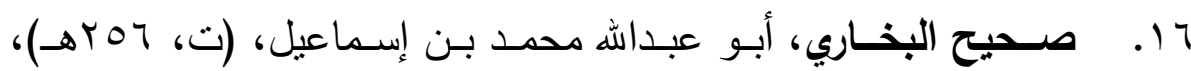
مطبعـة دار ابـن كثبـر ، البمامـة، مراجعـة د. مصـطفى ديـب البغـا، (ه. V V V IV . صحيح مسلم، أبو الحسن مسلم بن الحجاج النيسابوري، (ت، آYهـ)، مراجعة محمد فؤاد عبد الباقي، دار إحياء التراث العربي، بيروت، طبعة أهـ TVE

1 1. الصبر وأثره في حياة المسلم، الشيخ عبداله بن جار الله الجار الله. 9 1. فتح القدير، لمحمد بن علي الثـوكاني، (ت، .0 ب (هـ)، دار الكتب العلمية، بيروت، لبنان. - ان.

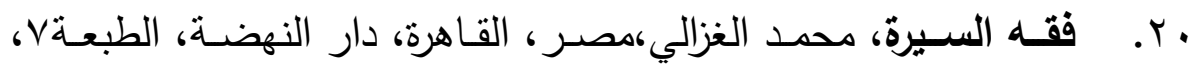
- $19 \vee 7$ 
ا.r. لـــان العـرب، محمد بن مكرم بن منظور الأفريقي المصـري، (ت، . (ه)

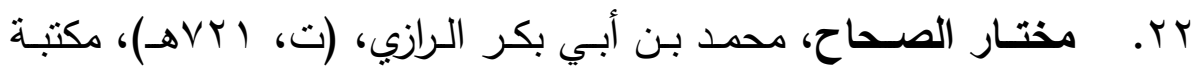

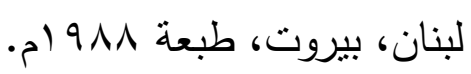

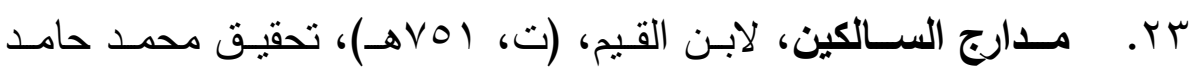

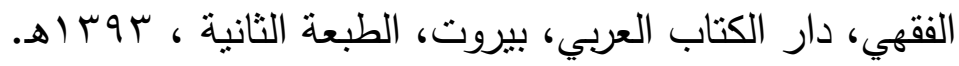

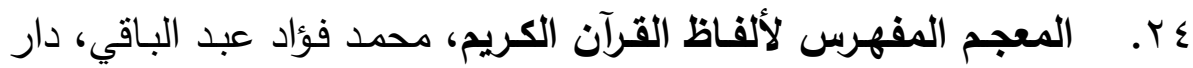
الحديث، مصر ، طبعة V •• اله.

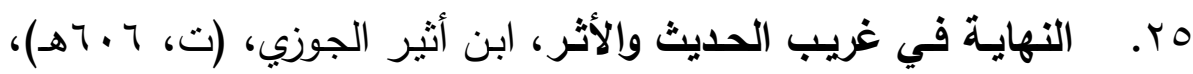

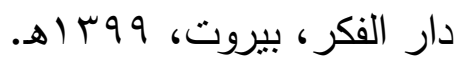

